\title{
半楕円斜め表面き裂のき裂面部分弾性接触シミュレーションによる 残留応力下の疲労き裂伝ぱ挙動の予測*
}

\author{
辻昌 宏*1, 徳増 裕 之*2, 久保 司 郎*3 \\ Predictions of Propagation Behavior of Semi-Elliptical \\ Slant Surface Cracks in Residual Stress Fields Based \\ on Simulations of the Partial Elastic Contact of Crack Surfaces
}

\author{
Masahiro TSUJI*4, Hiroyuki TOKUMASU and Shiro KUBO \\ ${ }^{* 4}$ Department of Mechanical Engineering, Osaka University, \\ 2-1 Yamadaoka, Suita-shi, Osaka, 565-0871 Japan
}

\begin{abstract}
In residual stress fields, the so-called partial elastic contact of crack surfaces sometimes occurs, where a fatigue crack is closed at the crack mouth while it is open at the crack tip. The partial elastic contact has a significant effect on the lives of fatigue cracks. However there are few studies on the partial elastic contact of crack surfaces for three-dimensional cracks. In this paper, the propagation paths and lives of semi-elliptical slant surface fatigue cracks are predicted. The finite element method was employed for these simulations. The residual stress was introduced by applying an equivalent nodal force in correspondence to an initial strain to each finite element. The results of the propagation paths and lives of simulations considering the partial elastic contact of crack surfaces differed from those without the consideration of the elastic contact. Especially the estimated results of crack propagation rate sometimes brought one-order difference. These results demonstrate the necessity of simulation considering the partial elastic contact of crack surfaces.
\end{abstract}

Key Words: Simulation, Semi-Elliptical Slant Surface Crack, Partial Elastic Contact, Fatigue Crack Propagation Path, Life Prediction, Residual Stress, Finite Element Method

\section{1. 緒言}

三次元き裂の伝ぱ挙動 ${ }^{(1)(2)}$ を詳細に調べることは, 実際の機械・構造物中において存在する傷や久陥が三 次元的であり, またそれらの健全性, 寿命延伸, コス 卜削減等のことを考慮すれば, 必要なことである. そ のため, それら三次元疲労き裂の伝ぱ寿命推定に対す る研究が行われてきたが, 三次元き裂の持つ複雑性の ため, そのき裂が荷重軸に対して垂直に伝ぱする場合 が多く扱われてきた ${ }^{(3) \sim(6)}$. しかしながら, 実際の構造 物中に存在するき裂では，荷重軸に対し斜めとなって いる場合が多々存在する.このような三次元斜めき 裂(1)(2)では, き裂伝ぱ挙動は複雑なものとなることが 予想され, き裂の伝ぱ方向をも含めた寿命推定を行う 必要も生じる.

また，これら三次元き裂に，傷やき裂等の欠陥と同 様に, 通常構造物中に存在すると考えられる残留応力

* 原稿受付 2007 年 3 月 26 日.

*1 正員, 大阪大学大学院工学研究科 (业565-0871 吹田市山田 丘 2-1).

*2 正員, 三菱重工業(株) 高砂製作所 (画 676-8686 高砂市荒井 町新浜 2-1-1).

*3 正員, フェロー, 大阪大学大学院工学研究科.

E-mail : mtsuji@mech.eng.osaka-u.ac.jp
が重畳した場合には，さらに複雑な現象が発生すると 考えられる. すなわち, き裂先端の塑性域が試験片寸 法に比べて十分に小さい小規模降伏条件下において， き裂がその先端で開口し，後方で閉口する「き裂面の 部分弾性接触」 ${ }^{(7)}$ が生じることが考えられる. このき 裂面の部分弾性接触が, 疲労き裂の寿命推定および疲 労き裂の伝ぱ経路に大きな影響を及ぼす可能性がある. そのため, 二次元き裂のき裂面の部分弾性接触に関す る研究が, すでにいくつかなされている(7)(8). ことに 三次元き裂では，き裂面各部の部分弾性接触の相互作 用が生じ, 現象がより複雑になるものと考えられる.

これらの複雑な状況下における三次元き裂の伝ぱ挙動 に関する研究は, 非常に困難であるため, まったく行 われていない.このため, 三次元斜めき裂のき裂面部 分弾性接触を考慮に入れた複合した状況下における詳 細な研究が必要であると思われる.

そこで, 本研究では，一般によく遭遇すると考えら れる半楕円斜め表面き裂に対して検討を行う.すなわ ち, き裂面の部分弾性接触が容易に生じると考えられ る分布型を持った残留応力場に存在する半楕円斜め表 
面き裂に対し，き裂面の部分弾性接触を考慮に入れた 疲労き裂伝ぱシミュレーションを有限要素法を用いて 行い，部分弾性接触が疲労き裂伝ぱ挙動に及ぼす影響 について調べる. 同時に，著者らが以前に提案した塑 性等によるき裂先端の開閉口挙動を, き裂開口比 $U$ と 実効応力比 $R$ との関係を用いることにより考慮した「U 予測による寿命推定法」 ${ }^{(9)}$ と「 $\Delta \sigma_{\theta}$ 最大説」 ${ }^{(10)(11)}$ と を組み合わせることにより，三次元的に複雑な伝ぱ経 路を示すき裂形状の推定をも試みる.

\section{2. き裂面での部分弾性接触と シミュレーション方法}

き裂が圧縮残留応力場から引張残留応力場へと伝ぱ するような場合, 圧縮残留応力の大きさによっては, 図 1 に示すように, き裂がその先端で開口し, 後方付 近で閉口する「き裂面の部分弾性接触」 ${ }^{(7)}$ が生じるこ とがある. この場合, き裂面後方では接触の発生した 面から接触抗力を受けることになり, 接触を考虑に入 れない場合と比較して, 接触を考慮に入れた場合のき 裂先端近傍の応力拡大係数は大きくなると考えられる. このため, 有限要素解析においてき裂面部分弾性接触 を考虑に入れ，モード I の応力拡大係数 $K$ の值が負と ならないような数值シミュレーションを行うことがよ り現実的である.

そこで本研究では, 繰返し荷重の除荷途中において, 互いに向かい合うき裂面間の荷重軸方向の相対変位が 負となった場合，そのき裂面上の節点を互いに固着さ せる弾性接触シミュレーションを行った. き裂面上の 節点を互いに固着させる弾性接触シミュレーションで

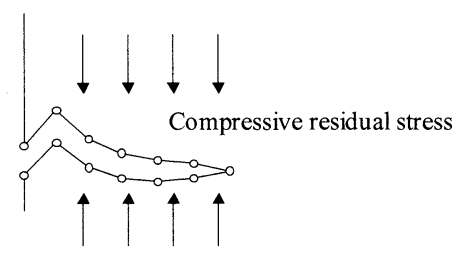

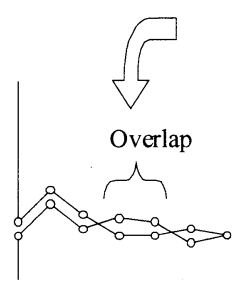

(a) Without considering contact

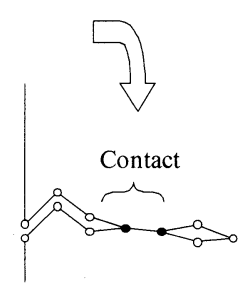

(b) With considering contact
Fig. 1 Partial elastic contact of crack surfaces
は, その影響のため, 解析に䛊差を生じる可能性も考 えられた. そこで, その拘束を解放した解析も一部行つ たが，本研究の範囲では，固着後解放した際のすべり の量は比較的小さく, 結果として, 固着した場合と固 着後解放した場合とで, 伝ば経路の差は認められな かった. また，二次元き裂ではあるが，著者らが過去 において行った実験の結果と, 固着した場合および固 着後解放した場合のシミュレーション結果との比

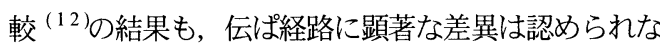
かった.

\section{3. 部分弾性接触を考虑に入れた応力拡大係数の 具体的算出方法}

き裂面の部分弾性接触が生じる場合, 数值計算上, 図 1(a)中に示したように, き裂面の上面と下面が部分 的に重なり, 応力拡大係数 $K$ および実効応力比 $R$ (= $\left.K_{\min } / K_{\max }\right)$ が負となる場合も存在する. そこで, 負の モードIの $K$ 值が生じないように応力拡大係数 $K$ を算 出した. 以下に, 簡単に手順を示す.

（1）初期残留応力分布を初期ひずみによる等価節点力 として有限要素弾性解析に導入 ${ }^{(11)} し$, 負荷応力 $\sigma_{\mathrm{ap}}=$ $\sigma_{\text {max }}$ として有限要素解析を行い, 最大応力拡大係数 $K_{\text {max }}$ を求める.

（2）負荷応力 $\sigma_{\mathrm{ap}}=\sigma_{1}$ および $\sigma_{\mathrm{ap}}=\sigma_{1}-C(\mathrm{MPa})$ で有限要 素解析を行い, き裂面上の節点 $i$ と, それと向かい合 うもう一方のき裂面上の節点との, 荷重軸方向の負荷 応力 $\sigma_{1}$ の場合の相対変位 $u_{1 i}$ および負荷応力 $\sigma_{1}-C$ の 場合の相対変位 $u_{2 i}$ を求める.ただし, $C$ は定数であり, 本研究では経験的に $C=100(\mathrm{MPa})$ とした.

(3) 手順(2)で求めた二つの相対変位 $u_{1 i}$ および $u_{2 i}$ を用い て, 節点 $i$ における相対変位が 0 となるような負荷応 力 $\sigma_{\mathrm{tch}, i}$ を, 次式により求める.

$$
\sigma_{\mathrm{tch}, i}=\sigma_{\mathrm{ap}}-\frac{C \cdot u_{1 i}}{u_{1 i}-u_{2 i}}
$$

次に, それらの值を大きい順に並べ, その $n$ 番目の 值を新たな負荷応力 $\sigma_{\mathrm{a}}$ とする. すなわち, ここで求 めた負荷応力 $\sigma_{\mathrm{ap}}$ においては, 新たに $n$ 個のき裂面上 の節点で接触が生じることになる. 本研究では, $n$ の 最大值については, 経験的に 20 とした.

(4) 手順(3)で求めた $n$ 個の節点について, き裂面上の 節点を互いに固着させる.

(5) 手順(3)で求めた負荷応力 $\sigma_{\mathrm{ap}}$ が最小負荷応力 $\sigma_{\mathrm{min}}$ 以下になるまで手順(2)から手順(4)を繰り返し， $\sigma_{\text {min }}$ 以下の值となった場合， $\sigma_{\mathrm{tch}, ~}$ が $\sigma_{\mathrm{min}}$ 以上の值をもつ節 
点を固着させ, 負荷応力を $\sigma_{\min }$ として有限要素弾性解 析を行い, その際の応力拡大係数を $K_{\min }$ とする.

以後, モードIの $K$ 值が負とならないように上記の 手順にしたがって応力拡大係数 $K$ を求めた場合を, 「き裂面の部分弾性接触を考慮に入れた場合」と呼び, 上記の計算を行わず，従来通り負の $K$ 値を許容して計 算した場合を，「き裂面の部分弾性接触を考慮に入れ ない場合」と呼ぶことにする.

三次元弾性解析で用いる有限要素としては, 二次の 形状関数をもつ6面体20節点アイソパラメトリック要 素(13)を用い, き裂先端近傍にはBarsoum ${ }^{(14)}$ の特異要素 を配置した. また, 初期残留応力を初期ひずみによる 等価節点力として有限要素法に組み込んだ(11). き裂先 端の応力拡大係数の評価には, 変位法 ${ }^{(15)}$ を用いた. 以 上のように, き裂面の部分弾性接触を考慮に入れた最 大応力拡大係数 $K_{\text {max }}$ および最小応力拡大係数 $K_{\text {min }}$ を算 出し, これらの值を「U 予測による寿命推定法」 ${ }^{(9)} お$ よび「 $\Delta \sigma_{\theta}$ 最大説」 ${ }^{(10)(11)} に$ 適用した.

\section{4. 三次元斜めき裂の疲労き裂伝ぱ寿命推定}

4 ・1 U予測による寿命推定法 ${ }^{(9)}$ の概略 「U 予測 による寿命推定法」 ${ }^{(9)}$ は, モード I におけるき裂伝 ば(3) (6)を対象としている. 本研究のようにき裂がわん 曲するような場合においては, き裂先端のモードは, モードI, モードI, およびモードIII各成分が存在 する混合モードとなる. したがって, 寿命を推定する 際にどのようなモードの $K$ 值を採用するかが問題とな る.「 $\Delta \sigma_{\theta}$ 最大説」 ${ }^{(10)(11)}$ によれば, わん曲しながら 伝ぱする疲労き裂の場合においても, き裂は常に $\Delta \sigma_{\theta}$ が最大となる方向を選択しつつ伝ぱする. それゆえ, き裂伝ぱ速度を支配するパラメー夕は, モードI の応 力拡大係数であると考えられる. したがって, き裂伝 ぱ速度は, 絽返し荷重による $\Delta K_{\mathrm{I}}$ および最大荷重時の 実効応力拡大係数 $K_{\text {I } \max }$ によって支配されるものと考 えられる. 本研究では, 以上の考えのもとに, $\Delta K_{\mathrm{I}}$ お よび $K_{\text {I max }}$ を, 三次元き裂前縁各点の各時点における き裂伝ぱ速度推定のパラメータとして用いた. 具体的 な手順を簡単に以下に述べる.

(1) 初期残留応力分布を初期ひずみによる等価節点力 として有限要素法に組み込み ${ }^{(11)}$, 前章で説明したき裂 面部分弾性接触を考慮に入れた応力拡大係数算出方法 にしたがって，き裂前縁各点におけるモード I および モードIの最大応力拡大係数 $K_{\text {I max }}$ および $K_{\text {Imax }}$ を算出 する. また同様に, 最小応力拡大係数 $K_{\text {I min }}$ および $K_{\text {II min }}$ をそれぞれ算出する. なお，ここで用いた有限
要素解析は，小規模降伏状態を前提とした弾性解析で ある. 求めた $K_{\text {I max }}$ および $K_{\text {I min }}$ の值を次式に代入し,

$$
R=\frac{K_{\mathrm{I} \min }}{K_{\mathrm{I} \max }}
$$

き裂前縁各点における実効応力比 $R$ を求める.

(2) 初期残留応力が存在しない二次元き裂試験片を用 いた, 疲労き裂伝ぱ実験の結果より, き裂開口比 $U$ と 実効応力比 $R$ の関係を求め, この関係と実効応力比 $R$ よりき裂開口比 $U$ を推定する. また, 次式により応力

$$
\left\{\begin{array}{l}
\Delta K_{\mathrm{I}}=K_{\text {I max }}-K_{\text {I min }} \\
\Delta K_{\text {II }}=K_{\text {II max }}-K_{\text {II min }}
\end{array}\right.
$$

拡大係数範囲 $\Delta K_{\mathrm{I}}$ および $\Delta K_{\text {II }}$ を求め, このうちの $\Delta K_{\mathrm{I}}$ とき裂開口比 $U$ から有効応力拡大係数範囲 $\Delta K_{\text {I eff }}\left(=U \cdot \Delta K_{\mathrm{I}}\right)$ を推定する.

(3) 手順(2)で求めた有効応力拡大係数範囲 $\Delta K_{\text {I eff }}$ と, 先の初期残留応力が存在しない二次元き裂試験片を用 いた疲労き裂伝ぱ実験の結果より得られた，き裂伝ぱ 速度 $d a / d N$ と $\Delta K_{\text {Ieff }}$ との関係より, き裂前縁各点での き裂伝ぱ速度を求める。このき裂伝ぱ速度から, き裂 前縁各点におけるその時のき裂の伝ぱ増分量を決定す る.

(4) 応力拡大係数範囲 $\Delta K_{\mathrm{I}}$ および $\Delta K_{\text {II }}$ を用いて, $\left\lceil\Delta \sigma_{\theta}\right.$ 最大説」(10)(11)により伝ぱ方向を決定する. き 裂前縁各点において, その求められた伝ぱ方向に沿つ て, き裂を, 先ほど求めた伝ぱ増分量だけ伝ぱさせる ことにより，新しいき裂前縁形状を決定する.

なお，本研究においては，モードIII成分も存在し， この成分がき裂伝ぱ方向に影響を与える可能性も考え られる. しかしながら，モード且成分の寄与は小さい ことと, 計算の複雑さからモード而成分については考 慮に入れなかった ${ }^{(2)}$.

以上の一連の手順, すなわち, 疲労き裂伝ぱシミュ レーションを繰り返すことにより, 残留応力場におけ る三次元斜め疲労き裂の伝ば経路および寿命を予測す ることができる.

なお，「U 予測による寿命推定法」 ${ }^{(9)}$ を用いた疲労 き裂伝ぱシミュレーションには, 無残留応力試験片に 対するき裂開口比 $U$ と実効応力比 $R$ との関係, および き裂伝ぱ速度 $d a / d N$ と有効応力拡大倸数範囲 $\Delta K_{\text {I eff }}$ と の関係が必要である. 本研究では, 材料として S35C 材を想定し、過去に発表したデータ乹を基に, 以下の 式を用いた。 
・ き裂開口比 $U$ と実効応力比 $R$ との関係

$$
\left.\begin{array}{ll}
U=\frac{1}{1.3897-0.8742 R+0.2397 R^{2}} & (R<0.52) \\
U=1.0 & (R \geq 0.52)
\end{array}\right\}
$$

・き裂伝ぱ速度 $d a / d N$ と有効応力拡大係数範囲 $\Delta K_{\text {I eff }}$ との関係

$$
\begin{aligned}
& d a / d N=6.13 \times 10^{-12}\left(\Delta K_{\text {I eff }}\right)^{3.40} \\
& \left(d a / d N: \mathrm{m} / \text { cycle, }, \Delta K_{\text {Ieff }}: \operatorname{MPa} \sqrt{\mathrm{m}}\right)
\end{aligned}
$$

\section{$4 \cdot 2$ 疲労き裂伝ぱ経路を与える $\Delta \sigma_{\theta}$ 最大} 説(10) (11) の概略 き裂伝ぱ方向を与えるクライテリ オンとして種々のものが発表されているが, 本研究に おいては, 現在のところ, 比較的物理的意味が明確と 考えられ，大路ら ${ }^{(16)(17)}$, 西谷ら ${ }^{(18)}$ および田中ら ${ }^{(19)}$ によって有力であることが示された $「 \Delta \sigma_{\theta}$ 最大 説」(10)(11)を採用した.この説に従えば, き裂は $\Delta \sigma_{\theta}$ が 最大となる方向に伝ぱする. すなわち, き裂の延長線 方向からの伝ぱ方向のずれ $\theta_{0}$ は, 次式で与えられる.

$$
\theta_{0}=2 \tan ^{-1}\left(\frac{1 \pm \sqrt{1+8 r^{\prime 2}}}{4 r^{\prime}}\right)
$$

ここで

$$
r^{\prime}=\frac{\Delta K_{\mathrm{II}}}{\Delta K_{\mathrm{I}}}
$$

である. 式(6)より得られる 2 根の内，大きな $\Delta \sigma_{\theta}$ を 与える根が求めるき裂の伝ぱ方向を与える. ここで, $\Delta \sigma_{\theta}$ は次式により与えられる。

$$
\Delta \sigma_{\theta}=\cos \left(\frac{\theta_{0}}{2}\right) \cdot\left(\Delta K_{\mathrm{I}} \cdot \cos ^{2}\left(\frac{\theta_{0}}{2}\right)-3 \cdot \Delta K_{\mathrm{II}} \cdot \frac{\sin \theta_{0}}{2}\right)
$$

\section{5. 部分弾性接触を考慮に入れたき裂開閉口 シミュレーション}

残留応力下の斜め表面き裂の開閉口挙動に及ぼす部 分弾性接触の影響を調べるため, き裂開閉口シミュ レーションを行った.

$5 \cdot 1$ 解析対象および解析条件 図 2 に示した半 棈円斜め表面き裂を有する平板を解析対象とした. 解 析対象中央部の, $Y-Z$ 面に関して対称性があるものと し, 解析対象の上下端で一様引張り荷重が作用してい るものとした. 図中に示したように，き裂の深さ方向
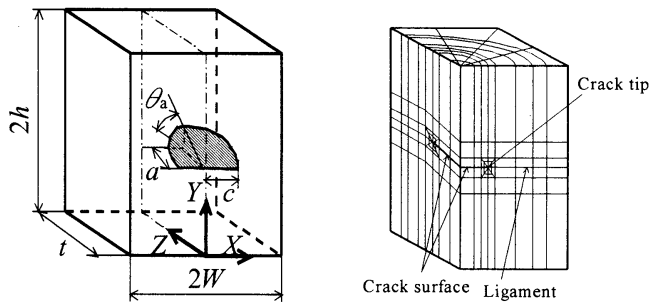

Fig. 2 Model with slant surface Fig. 3 An example of finite crack used for analysis
(Z方向)に対してき裂がもつ角度を $\theta_{\mathrm{a}}$ で表した. また, き裂の深さ方向寸法を $a$, き裂の表面方向寸法を $2 c$ と した. 本報中では簡単のために, 以後, $a$ をき裂深さ, および $c$ をき裂表面長さと呼ぶことにする.

本研究では, 対称性を利用して, 解析対象全体の $1 / 2$ の部分に対して三次元有限要素弾性解析を行った. 解 析条件を表 1 に示す. また, 解析において要素分割を 行うにあたり, 解析対象の各方向における要素分割数 および分割方法に関して与えた条件を表 2 に示す。さ らに, 要素分割の一例を図 3 に示す. なお, 本研究に おいて用いた「U予測による寿命推定法」(9)では，き 裂先端近傍の開閉口を, き裂開口比 $U$ と実効応力比 $R$ との間の関係で考慮しているため, 図 3 に示すよう な比較的粗いメッシュを用いても，き裂伝ぱの傾向を 調べることができる

また, 本研究では, 材料として S $35 \mathrm{C}$ 材 ${ }^{(9)}$ を想定した. $\lceil U$ 予測による寿命推定法」(9)を用いた疲労き裂伝ぱ シミュレーションに必要な, 無残留応力試験片に対す るき裂開口比 $U$ と実効応力比 $R$ との間の関係式, およ びき裂伝ぱ速度 $d a / d N$ と有効応力拡大係数範囲 $\Delta K_{\text {I fff }}$

Table 1 Conditions of analysis

\begin{tabular}{|c|cc|c|}
\hline \multirow{3}{*}{$\begin{array}{c}\text { Configuration } \\
\text { of plate model }\end{array}$} & Thickness & $: t$ & $20.0(\mathrm{~mm})$ \\
\cline { 2 - 4 } & Half width & $: W$ & $20.0(\mathrm{~mm})$ \\
\cline { 2 - 4 } & Half length & $: h$ & $80.0(\mathrm{~mm})$ \\
\hline \multirow{2}{*}{$\begin{array}{l}\text { Initial crack } \\
\text { configuration }\end{array}$} & Depth & $: a$ & $6.0(\mathrm{~mm})$ \\
\cline { 2 - 4 } & Length & $: c$ & $6.0(\mathrm{~mm})$ \\
\cline { 2 - 4 } & Angle & $: \theta_{\mathrm{a}}$ & $30^{\circ}$ \\
\hline \multirow{2}{*}{ Material constants } & Young's modulus & $: E$ & $206.0(\mathrm{GPa})$ \\
\cline { 2 - 4 } & Poisson's ratio & $: v$ & 0.3 \\
\hline
\end{tabular}

Table 2 Conditions of finite element discretization

\begin{tabular}{|c|c|c|}
\hline \multirow{2}{*}{$\begin{array}{c}\text { Number } \\
\text { of divisions }\end{array}$} & Radial direction & 8 \\
\cline { 2 - 3 } & Longitudinal direction & 6 \\
\cline { 2 - 3 } & Circumferential direction & 4 \\
\hline \multicolumn{2}{|r|}{ Total number of elements } & 240 \\
\hline
\end{tabular}




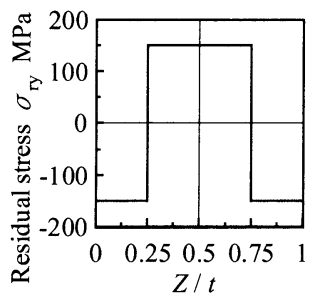

Fig. 4 Initial residual stress distribution in $Y$-direction

Table 3 Ratio $r_{\mathrm{da} / \mathrm{dN}}$ of $d a / d N_{\mathrm{w} \text {. contact }}$ with consideration of elastic contact and $d a / d N_{\text {w.o. contact }}$ without consideration of elastic contact $(a / t=0.3, c / W=0.3)$

\begin{tabular}{|c|c|c|c|c|c|c|}
\hline \multirow{2}{*}{\multicolumn{2}{|c|}{$r_{\mathrm{da} / \mathrm{dN}}$}} & \multicolumn{5}{|c|}{$\sigma_{\max }(\mathrm{MPa})$} \\
\hline & & 120 & 150 & 180 & 210 & 240 \\
\hline \multirow{4}{*}{$0^{\prime} 0^{\prime}$} & 0.6 & 0.093 & 0.11 & 0.22 & 0.46 & 0.72 \\
\hline & 0.4 & 0.12 & 0.14 & 0.20 & 0.36 & 0.52 \\
\hline & 0.2 & 0.20 & 0.19 & 0.28 & 0.43 & 0.53 \\
\hline & 0.0 & 0.27 & 0.32 & 0.37 & 0.46 & 0.53 \\
\hline
\end{tabular}

との間の関係式としては, 4・1 節で示した式(4)および (5)を用いた。

本研究で用いた $Y$ 方向初期残留応力の $Z$ 軸方向の分 布を図 4 に示す. 計算を簡単にするため, き裂面内に は $Y$ 方向の初期残留応力分布のみが存在するものと仮 定した. 図 4 中に示した初期残留応力分布は，3 枚の 平板を貼り合わせる際等に発生することが予想される 分布形 ${ }^{(5)}$ であり, き裂面の部分弾性接触の影響が比較 的良く現れる分布形となっている.

$5 \cdot 2$ 解析結果 図 5 に, $X-Z$ 面へ投影したき裂 前縁形状を示す. 表 3 にき裂深さ $a / t=0.3$, およびき裂 表面長さ $c / W=0.3$ の場合の, 図 5 中に示したき裂前縁 上の点 $\mathrm{A}$ における伝ぱ速度 $d a / d N$ の解析結果を示す. 表中の最上段の数値は, 最大負荷応力 $\sigma_{\max }$ を表し, 最 左列の数值は, 最大負荷応力に対する最小負荷応力の 比 $\sigma_{\min } / \sigma_{\max }$ を表している. また, 表中の值は, 次式

$$
r_{\mathrm{da} / \mathrm{dN}}=\frac{d a / d N_{\mathrm{w} . \text { contact }}}{d a / d N_{\text {w.o. contact }}}
$$

に示す接触を考慮に入れない場合の伝ぱ速度 $d a / d N_{\text {w.o. contact }}$ に対する，接触を考慮に入れた場合の 伝ぱ速度 $d a / d N_{\text {w. contact }}$ の比 $r_{\mathrm{da} / \mathrm{dN}}$ を示している. 表 3 中 に示す荷重範囲においては，き裂面の部分弾性接触が 生じている. その一例として, $\sigma_{\max }=180 \mathrm{MPa}$ および $\sigma_{\min } / \sigma_{\max }=0.0$ の場合におけるき裂面の接触状態を

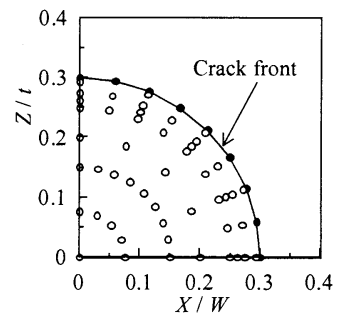

(i) $\sigma / \sigma_{\max }=1.0$

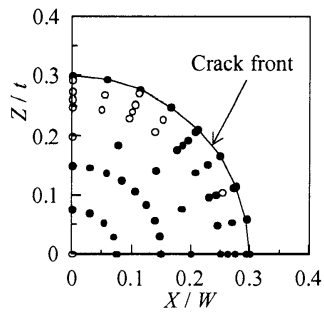

(iii) $\sigma / \sigma_{\max }=0.84$

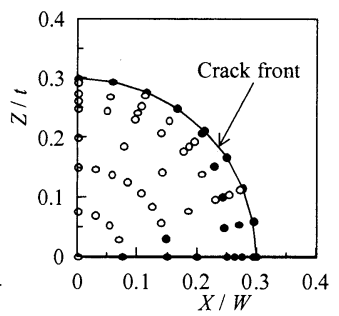

(ii) $\sigma / \sigma_{\max }=0.92$

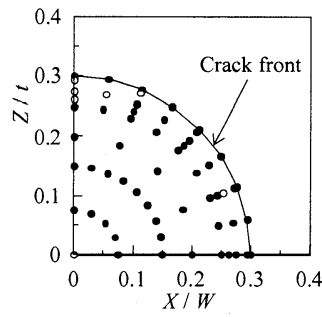

(iv) $\sigma / \sigma_{\max }=0.0$
Fig. 6 Contact steps of fracture surfaces in $a / t=c / W=0.3$ ( $\sigma_{\max }=180 \mathrm{MPa}, \sigma_{\min } / \sigma_{\max }=0.0 ; \bigcirc$ :open, $\mathrm{O}$ contact)

図 6 に示す. 図中の中空印 $(\bigcirc)$ は開口している節点 を, 中実印（○）は閉口している節点を表している. 図 6 より, 負荷荷重が減少するにしたがい, き裂表面 部からき裂深さ方向にき裂面が閉じていく様子がわか る. 最小応力負荷時にも, き裂表面方向 $(X$ 方向)の先端 部（図 5 中のき裂前縁上の点 A) は開口しており, き 裂面の部分弾性接触が生じていることがわかる.

また, 表 3 より, き裂面の部分弾性接触が生じてい る状況下においては，接触を考慮に入れて解析を行っ た場合と接触を考慮に入れずに解析を行った場合とで, き裂先端点 $\mathrm{A}$ における伝ぱ速度 $d a / d N$ の值に $1 / 10$ 程度 の大きな差が存在していることがわかる. さらに, 負 荷応力 $\sigma_{\max }$ が小さい程, その差は大きなものとなって いることがわかる.

\section{6. 部分弾性接触を考虑に入れた疲労き裂伝ぱ}

$$
\text { シミュレーション }
$$

部分弾性接触が半棈円斜めき裂の伝ぱ挙動に及ぼす 影響を調べるため, 部分弾性接触を考慮に入れて得ら れるき裂先端各点のき裂開口比 $U$ と応力拡大係数 $K$ か ら伝ぱ速度 $d a / d N$ を計算し, これに合わせて逐次き裂 を伝ぱさせる疲労き裂伝ぱシミュレーションを行った.

6・1 シミュレーション条件およひ方法 解析条 件を表 4 に示す. 疲労き裂伝ぱシミュレーションにお ける初期き裂寸法を, き裂深さ $a / t=0.20$ およびき裂表 
Table 4 Conditions of analysis

\begin{tabular}{|c|cc|c|}
\hline \multirow{2}{*}{$\begin{array}{c}\text { Configuration of } \\
\text { plate model }\end{array}$} & Thickness & $: t$ & $20.0(\mathrm{~mm})$ \\
\cline { 2 - 4 } & Half width & $: W$ & $20.0(\mathrm{~mm})$ \\
\cline { 2 - 4 } & Half length & $: h$ & $80.0(\mathrm{~mm})$ \\
\hline \multirow{2}{*}{$\begin{array}{c}\text { Initial crack } \\
\text { configuration }\end{array}$} & Depth & $: a$ & $4.0(\mathrm{~mm})$ \\
\cline { 2 - 4 } & Length & $: c$ & $4.0(\mathrm{~mm})$ \\
\cline { 2 - 4 } & Angle & $: \theta_{\mathrm{a}}$ & $30^{\circ}$ \\
\hline \multirow{2}{*}{ Material constants } & Young's modulus & $: E$ & $206.0(\mathrm{GPa})$ \\
\cline { 2 - 4 } & Poisson's ratio & $: v$ & 0.3 \\
\hline
\end{tabular}

Table 5 Conditions of finite element discretization

\begin{tabular}{|c|c|c|}
\hline \multirow{2}{*}{$\begin{array}{c}\text { Number } \\
\text { of divisions }\end{array}$} & Radial direction & 14 \\
\cline { 2 - 3 } & Longitudinal direction & 6 \\
\cline { 2 - 3 } & Circumferential direction & 4 \\
\hline \multicolumn{2}{|c|}{ Total number of elements } & 384 \\
\hline
\end{tabular}

面長さ $c / t=0.20$ とした. 荷重条件を, $\sigma_{\text {max }}=210 \mathrm{MPa}$ および $\sigma_{\mathrm{min}}=0 \mathrm{MPa}$ とした. 初期き裂角度を, $\theta_{\mathrm{a}}=30^{\circ}$ とした. また, 対称性を利用して, 解析対象全体の $1 / 2$ の部分に対して三次元有限要素弾性解析を行った. 解 析において要素分割を行うにあたり, 解析対象の各方 向における要素分割数および分割方法に関して与えた 条件を表 5 に示す.

なお，本研究で用いた $Y$ 方向初期残留応力の $Z$ 軸方 向の分布は, 図 $4^{(5)}$ 亡同じ分布型である. ただし, 最大 值および最小值は, おのおの $120 \mathrm{MPa}$ およびー120MPa とした.

6.2 伝ぱ速度の推定結果 き裂前縁に沿う,伝ぱ 速度 $d a / d N$ の分布を図 7 に示す. 図中の横軸は, 図 5 中に示したき裂前縁形状を表す角度 $\phi$ 無次元化した ものである. すなおち, $2 \phi / \pi=0$ はき裂最深部に対 応し, $2 \phi / \pi=-1$ および 1 はき裂表面部に対応してい る. 図 7 中では, き裂形状の対称性により $0 \leqq 2 \phi / \pi$ $\leqq 1$ の範囲のみを示した. 図 7 中の中実印

および○）は，き裂面の部分弾性接触を考慮に入れな

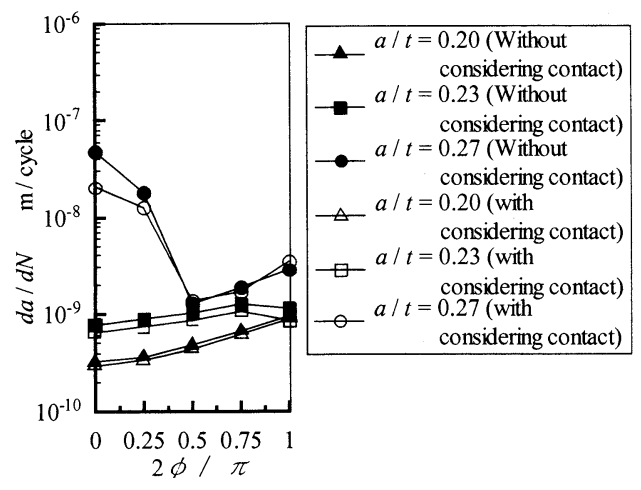

Fig. 7 Crack propagation rates along crack fronts

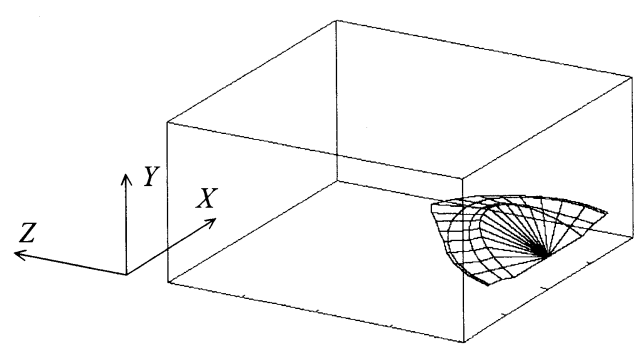

(a) Without considering contact

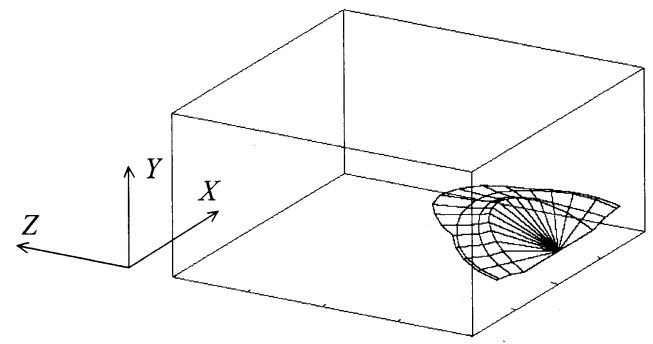

(b) With considering contact

Fig. 8 Estimated crack front shapes

い場合の解析結果を, 中空印 $(\triangle, \square$, および○) は, 接触を考慮に入れた場合の解析結果を表している. 図 より, $a / t=0.27$ の場合 $(\mathbf{O}$, および $), 2 \phi / \pi=0$ の点，すなわち，き裂最深部においては，接触を考慮 に入れた場合の伝ぱ速度 $d a / d N$ の值が，接触を考慮に 入れない場合の $d a / d N$ の值に比べて, 5 分の 2 程度の 大きさになっており, 両者の結果に差が生じているこ 亡がわかる。

6.3 伝ば経路の推定結果図 8 に, 伝ぱ経路の推定 結果を示す. 図 8 (a)は残留応力が存在し, き裂面の部 分弾性接触を考慮に入れない場合, (b)は残留応力が存 在し, き裂面の部分弾性接触を考慮に入れた場合の解 析結果をそれぞれ示している. なお，き裂形状の対称 性より,解析対象の $1 / 2$ の部分に対しての夕解析を行つ たが, 図 8 中には, 対称性を用いてき裂全体を描いた. 図より, き裂最深部周辺の伝ぱ速度の差の影響のため, き裂面の部分弾性接触を考慮に入れない場合と，考慮 に入れた場合とで，き裂前縁形状に差異が生じている のがわかる.

また，図 9 に図 8 におけるき裂中央部の深さ方向 $(Z$ 方向 : 図 9 (a))および表面方向 $(X$ 方向 : 図 9 (b))へのき 裂伝ぱ経路を，各方向について，き裂面の部分弾性接 触を考慮に入れない場合と，考慮に入れた場合と比較 したものを示す. 図より，き裂中央部の深さ方向に対 しては，き裂面の部分弾性接触を考慮に入れない場合 


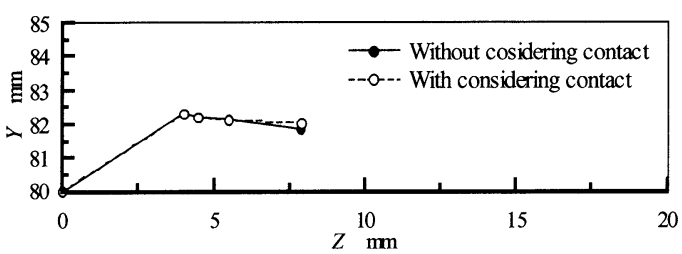

(a) In $Z$ direction

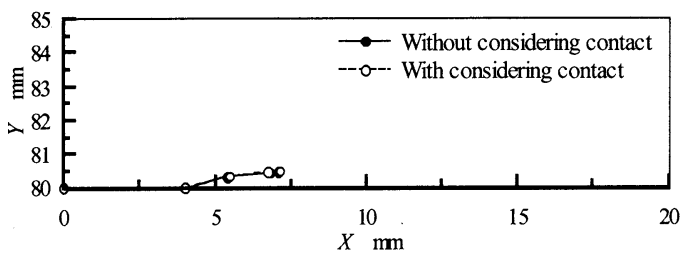

(b) In $X$ direction

Fig. 9 Estimated crack propagation path of each direction

と入れた場合とで，わずかではあるが，両者に差が生 じているのがわかる，一方，表面方向のき裂伝ぱ経路 に対しては，両者の差はほとんど認められない.

\section{7. 結}

三次元斜めき裂を有する解析対象に対して，き裂面 の部分弾性接触を考慮に入れた疲労き裂伝ぱシミュ レーションを行った. 同時に, 部分弾性接触を考慮に 入れない疲労き裂伝ぱシミュレーションも行い, 両者 の結果を比較・検討することにより，き裂面の部分弾 性接触が疲労き裂の伝ぱ寿命および伝ぱ経路の予測に およぼす影響について調べた，得られた結果を，以下 にまとめて示す.

（1）初期残留応力および負荷応力の大きさによっては, き裂面の部分弾性接触を考慮に入れた場合の伝ぱ速 度の推定結果は，接触を考慮に入れない場合の推定 結果に比べて, 10 分の 1 程度になる場合も存在し, き裂面の部分弾性接触が伝ぱ速度の推定に大きな影 響を及ぼす場合が存在することがわかった.

（2）半楕円斜め表面き裂において，き裂面の部分弾性 接触を考慮に入れない場合と入れた場合とで，き裂 前縁形状およびき裂伝ぱ経路が異なる場合が存在す る可能性が示された.

\section{謝辞}

本研究は, 学術振興会科学研究費補助金基盤研究 $(C)$ の援助を得て行われたものである. 記して謝意を表す.

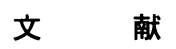

(1) K. Tohgo, Zairyou-Kyoudo Kaiseki-Gaku (in Japanese), (2004), pp. 161-191, Uchida Roukakuho.

(2) Y. Mi, Three-Dimensional Analysis of Crack Growth, (1996), Computational Mechanics Publications.

(3) M. Tsuji, M. Togami, K. Ohji, and S. Kubo, Prediction of Propagation Behavior of A Quarter-Elliptical Corner Fatigue Crack in Clad Steel with Residual Stresses, Transactions of the Japan Society of Mechanical Engineers, Series A, Vol.62, (1996), pp.1152-1157.

(4) K. Ohji, S. Kubo, and M. Tsuji, Mechanical Behavior of Materials VI, Vol.2, (1991), pp.233-239, Pergamon Press.

(5) M. Tsuji, K. Ohji, S. Kubo, M. Togami and T. Kanazawa, Life Prediction and Observations of Crack Closure Behavior of Surface Fatigue Cracks in PMMA with Residual Stresses, Transactions of the Japan Society of Mechanical Engineers, Series A, Vol.63, (1997), pp.2290-2297.

(6) M. Tsuji, K. Ohji and S. Kubo, Fatigue, Fracture, and High Temperature Design Methods in Pressure Vessels and Piping, PVP-Vol.365, (1998), pp.353-362, The American Society of Mechanical Engineers

(7) Y. Mukai, M. Murata and E. Kim, A proposal for Stress Intensity Factor Range Calculation Method by Partial Opening Model of Fatigue Crack Under Weld Residual Stress Field and Prediction of the Crack Propagation Behavior, Quarterly Journal of the Japan Welding Society, Vol.5, (1987), pp.269-272.

(8) A, Todoroki, H, Kobayashi and H, Nakamura, Prediction of Fatigue Crack Growth Rate in Residual Stress Field, Transactions of the Japan Society of Mechanical Engineers, Series A, Vol.54, (1988), pp.205-211.

(9) K. Ohji, S. Kubo, M. Tsuji, H. Ogawa and K. Sakurada, Methods of Predicting Fatigue Crack Growth Lives in Residual Stress Fields, Transactions of the Japan Society of Mechanical Engineers, Series $A$, Vol.53, (1987), pp.1516-1524.

(10) H. Kitagawa, R. Yuuki and $\mathrm{K}$, Tohgo, $\mathrm{K}_{\mathrm{I}}$ to $\mathrm{K}_{\mathrm{II}}$ no Kongou-Mohdo-Kiretsu Karano Hirou-KiretsuSeichou Kyodou, Transactions of the Japan Society of Mechanical Engineers, Series A, Vol.47, (1981), pp.1283-1292.

(11) K. Ohji, M. Tsuji, S. Kubo, Y. Ono, A. Yahata and K. Umei, Prediction of Fatigue Crack Propagation Path and Life of High-Tension Steel in Residual Stress Fields, Transactions of the Japan Society of Mechanical Engineers, Series A, Vol.59, (1993), pp.1429-1436.

(12) M. Tsuji, S. Kubo and M.Murayama, Propagation simulations of curved fatigue cracks in residual stress fields with considering the elastic contact, Proceedings of the $44^{\text {th }}$ Japan Congress on Materials Research, (2000-9),pp.139-140.

(13) T. Miyoshi, Yuugen-Youso-Hou $\sim$ Kouzou-Youso no Henkei Hakai-Kyodo no Kaiseki (in Japanese), (1976), Jikkyou Shuppan.

(14) R. S. Barsoum, On the Use of Isoparametric Finite Elements in Linear Fracture Mechanics, International Journal for Numerical Methods in Engineering, Vol.10, (1976), pp.25-37.

(15) C. F. Shih, H. G. deLorenzi and M.D. German, Crack Extension Modeling with Singular Quadratic Isoparametric Elements, International Journal of Fracture, Vol.12, (1976), pp.647-649.

(16) K. Ohji, S. Kubo, and M. Tsuji, Residual Stress - III, Science and Technology, Vol.1, (1992), pp.476-481, 
Elsevier Science Publishers Ltd.

(17) K. Ohji, T. Tsujikami and K, Hiraoka, Experimental Simulation of Propagating Paths of Fatigue Cracks Near or Across the Interface of Bonded Dissimilar Materials by Using the Proposed Equivalent Specimens, Journal of the Society of Materials Science, Japan, Vol.49, No.1, (2000), pp.879-884.

(18) H. Nisitani, T. Takeno, K. Fukuyama, N. Tatibana and A. Saimoto, Fatigue Crack Propagating
Behavior in A Strip and Its Simulation Analysis, Journal of the Society of Materials Science, Japan, Vol.49, (2000), pp.879-884.

(19) K. Tanaka, Y, Akiniwa, T. Kato and H. Takahashi, Prediction of Fatigue Crack Propagation Path from A Pre-Crack Under Combined Torsional and Axial Loading, Transactions of the Japan Society of Mechanical Engineers, Series A, Vol.71, (2005), pp.607-614. 